THE GREAT DIVERGENCE IN SOUTH AFRICA: POPULATION AND WEALTH DYNAMICS OVER TWO CENTURIES

African economic history working paper series

No. 47/2019

Dieter von Fintel, Stellenbosch University

dieter2@sun.ac.za

Johan Fourie, Stellenbosch University 
ISBN 978-91-981477-9-7

AEHN working papers are circulated for discussion and comment purposes. The papers have not been peer reviewed, but published at the discretion of the AEHN committee.

The African Economic History Network is funded by Riksbankens Jubileumsfond, Sweden

For submissions, contact:

Erik Green

Department of Economic History

Lund University

P. O. Box 7083 


\title{
The great divergence in South Africa: Population and wealth dynamics over two centuries*
}

\author{
Dieter von Fintel ${ }^{\dagger}$ and Johan Fourie ${ }^{\ddagger}$
}

\begin{abstract}
Does wealth persist over time, despite the disruptions of historical shocks like colonisation? This paper shows that South Africa experienced a reversal of fortunes after the arrival of European settlers in the eastern half of the country. Yet this was not, as some have argued was the case elsewhere in colonial Africa, because of an institutional reversal. We argue, instead, that black South Africans found themselves at the mercy of two extractive regimes: those in "white South Africa and those in the "homelands. The political and economic institutions of each of those regimes favoured a small elite: in white South Africa, whites, and in the homelands, the black chiefs and headmen. Democracy brought inclusive institutions for black residents in white South Africa but not for those in the former homelands. This is why we see mass migration to the urban areas of South Africa today, and why addressing the institutional weaknesses of the former homelands is key to alleviating the poverty in these regions where a third of South Africans still reside.
\end{abstract}

Keywords. reversal of fortunes, population persistence, institutional reversal, colonial impact, settler economy, African economic history, traditional leaders

\footnotetext{
${ }^{*}$ We thank the editor, three anonymous referees, Kara Dimitruk, Katherine Eriksson, James Fenske, Erik Green, Remi Jedwab, Martine Mariotti, James Robinson, participants at the ASSA meetings in San Francisco, the WEHC in Kyoto and the ESSA conference in Cape Town for valuable comments on an earlier version of the paper.

${ }^{\dagger}$ LEAP, Department of Economics, Stellenbosch University; Institute of Labor Economics (IZA), Bonn. E-mail: dieter2@sun.ac.za

${ }^{\ddagger}$ LEAP, Department of Economics, Stellenbosch University.
} 


\title{
The great divergence in South Africa: Population and wealth dynamics over two centuries
}

\author{
August 12, 2019
}

\section{Introduction}

Countries colonized by European powers during the past five centuries experienced a reversal of fortunes: those that were relatively rich in 1500 are now relatively poor. In their seminal contribution to African economic history, Acemoglu et al. (2002) show that pre-industrial population density is negatively correlated with modern-day income per capita. The result holds even when they include only African countries in their study sample.

The cause of this negative correlation, they argue, is the institutions established by Europeans in the colonies. Fewer Europeans settled in densely populated regions, and instead of introducing 'good' institutions (such as private property rights), these colonial powers imposed 'bad', extractive institutions. They say it was the poor institutional environment, rather than the geography, that made these countries poorer today than countries where 'good' institutions were set up. They note that the 'reversal in relative incomes' occurred mostly during the late eighteenth and early nineteenth centuries, and they argue that it 'resulted from societies with good institutions taking advantage of the opportunity to industrialise' (Acemoglu, Johnson, and Robinson 2002, p. 1231).

Not everyone accepts the validity of this hypothesis. More recently, Maloney and Caicedo (2016) have used sub-national pre-colonial population densities for eighteen countries in the Western hemisphere to show that population density has persisted up to today: those countries with highest concentrations in 1500 remain most densely populated. Importantly, those countries also have higher average income levels today, challenging Acemoglu et al.s hypothesis and suggesting wealth persistence instead.

We compare the merit of these two conflicting arguments by considering the case of South Africa over the past two hundred years. Our results show, firstly, that the settlement of black South Africans has been highly persistent: those areas that were populated primarily by this group in the 1830s and 1911 remain densely populated by their descendants today. At first, this appears to lend support to the argument of Maloney and Caicedo 
(2016): locational advantage determines persistence. But we argue that this is a simplistic interpretation of historical processes. The settlement patterns we observe in the 1830s are related to specific historical events, particularly conflicts within the Bantu-speaking peoples and the movement of European settlers into the interior of the country. As new archaeological evidence now shows, indigenous settlement patterns were very different only one century earlier. Although we find population persistence in the two centuries before 2011 (the date of the most recent South African census), it is unlikely that settlement patterns at the beginning of the nineteenth century reflected a stable, Malthusian equilibrium. Path dependence may be a better explanation for the observed trends than persistence.

When we consider measures of welfare, we find that the regions that were most densely populated early in the nineteenth century have today the highest unemployment rates and the lowest night lights luminosity. If we assume that high population density in this era reflects relative wealth - as it would have, given the devastating effects of the Mfecane - this seems to suggest that a reversal of fortunes occurred, of the kind that would support Acemoglu et al.s argument . But it is, again, not that simple. South Africa did not experience an institutional reversal: rather, black South Africans were subjected to extractive institutions in both 'white South Africa' and the homelands, the semi-autonomous polities that were formed around historically densely settled areas. The extractive institutions in these homelands were the result of a mixture of precolonial institutions and apartheid-era government influences. Democracy brought new institutional arrangements: black South Africans could now own property and vote in 'white South Africa, but were still subject to extractive institutions in the former homelands. The result was diverging economic outcomes for black South Africans, mitigated only by open borders and large out-migration.

Our paper expands the debate in three ways. First, past population density is often assumed to be correlated with income. At least during the pre-colonial era, when populations tended to rise with and offset any increases in wealth, this Malthusian argument appeared to be valid. We question this assumption in the case of South Africa. In particular, we argue that the slave trade and internal warfare may have obliged people to settle (even before colonial displacement) in areas that were not optimal for wealth accumulation following industrialisation - such as areas that were rugged or far from markets. Second, both Acemoglu et al. (2002) and Maloney and Caicedo (2016) include descendants of European settlers in their current-day estimates of population density and income. Their estimates are therefore confounded by other causal mechanisms (in addition to geography and institutions), such as cultural and genetic diversity. Our focus is only on the descendants of the indigenous, Bantu-speaking inhabitants of South Africa. The mechanism that explains the persistence or reversal of population density and wealth must be either geography or institutions. 
Third, we argue that the mechanism that Acemoglu et al.(2002) found to explain reversal of fortune, i.e. a change in institutions, does not explain the South African case. Black South Africans were generally excluded from economic and political rights in both "white South Africa and the former homelands. It was only towards the end of apartheid, and emphatically so after 1994, that these rights began to be shared more equally and the welfare of black South Africans in the former 'white areas began to improve. The same was not true in the former homelands, where the positions of chiefs and headmen became more entrenched, deepening the institutional divide. Migration from the former homelands to the cities has become the primary poverty alleviation strategy for black South Africans in the twenty-five years after the end of apartheid.

In short, our paper questions the premises of the persistence versus reversal debate. Black South Africans incomes have diverged enormously, not because of an institutional reversal, but because of idiosyncratic historical shocks that affected the timing and intensity of settler migration, the type of extractive institutions that were set up in both 'white South Africa and the homelands and the inability to move between these, and the institutional divergence after the start of democracy. As the case of South Africa shows, history is too complicated to be compressed into binary outcomes at the bookends of historical eras.

\section{Geography vs Institutions}

There is little doubt that both geography - the climate, terrain, disease and other environmental conditions - and institutions - the formal and informal 'rules of the game' - determine a region's development trajectory. The pertinent question is which of these two determinants acts as the core binding constraint towards further development. The answer would allow policy-makers to design policies that address these most urgent needs; if geography, then infrastructure investment or anti-malaria campaigns might be more appropriate, but if institutions, then the rule of law or protecting private property rights would matter more.

A vast literature has made a case for both. Poor geography, such as the presence of natural resources, a tropical climate or being landlocked, negatively predicts income in early cross-country regressions (Sachs and Warner 2001; Sachs and Warner 1997b; Sachs and Warner 1997a). Africa has few navigable rivers and most Africans live far from the coast (Collier and Gunning 1999). Africans are also more likely to live in rugged areas. Nunn and Puga (2012) argue that this is a consequence of the slave trade; in turn, the geographic patterns of the slave trade were influenced by climate shocks (Fenske and Kala 2015). Poor access to waterways and the rugged terrain inhibit trade, lowering the profitability of surplus production, providing no incentive for economic growth. 
A bad disease environment, such as the presence of malaria, also explains Africans' persistently low relative incomes (Gallup and Sachs 2001). Better identified empirical strategies have confirmed these earlier correlations, with many of the diseases that were studied being unique to Africa: river blindness (Kazianga, Masters, and McMillan 2014), the tsetse fly (Alsan 2014), and a range of diseases caused by the intensity of UV radiation (Andersen, Dalgaard, and Selaya 2016).

However, geography also matters for Acemoglu, et al. (2002)'s mechanisms; their instrumental variable is a spatially determined measure of the disease environment. Yet the mechanism through which they believe the past persists into the present is the institutional characteristics that formed society. A bad disease environment, Acemoglu, et al. (2002) argue, has little effect on the indigenous populations who have had time to build up immunities. Instead, a bad disease environment severely effects the arriving European settlers. In areas where tropical diseases decimate the European colonisers, extractive formal institutions are imposed that have detrimental consequences for economic development. In areas where Europeans did not suffer the consequences of a bad disease environment - such as in currentday South Africa - they settled and imposed institutions that are currently growth promoting.

The precise mechanism through which institutions explain Africa's poor economic performance has varied. Acemoglu, et al (2005, p. 397) somewhat vaguely refer to good institutions as those that promote 'private property', or which constitute a 'cluster of good economic institutions, including the rule of law and the enforcement of property rights'. Elsewhere, they pin the mechanism down more explicitly. The 'process of state formation' was delayed in Africa relative to Eurasia, and 'state institutions appear to have been intensely absolutist and patrimonial'. These pre-colonial institutions:

interacted in a perverse way with a series of shocks that hit Africa, in particular the slave trade in the early modern period, and colonialism in the 19th and 20th centuries. African countries emerged at independence with a complex path dependent set of institutions that were probably even worse than those which they had at the time of colonization (Acemoglu and Robinson 2010, p. 21).

Some have tried to empirically verify political institutions as the mechanism through which the African past effects the present (Gennaioli and Rainer 2007). Michalopoulos and Papaioannou (2013) compare the spatial distribution of ethnicities before colonisation with contemporary information on economic performance at the regional level. Even when controlling for local geographic features and other observable ethnic-specific characteristics, they find a strong link between pre-colonial ethnic political centralisation 
and regional development. But centralisation, according to Osafo-Kwaako and Robinson (2013), was not the result of high population density and trade, as was the case in Eurasia. In fact, higher population density in Africa was correlated with weaker degrees of centralization, and thus poorer development outcomes today: thus emerges an African reversal of fortune.

Political centralisation is, however, also correlated with other types of institutions. Colonial powers brought different legal systems (La Porta, Silanes, and Shleifer 2008). Missionaries promoted formal education (Gallego and Woodberry 2010; Frankema 2012; Cagé and Rueda 2016). Even the introduction of new crops affected land property rights; Fenske (2014) shows how the introduction of Brazilian rubber during the colonial period transformed land rights and land disputes in the Benin region of Nigeria. Rubber trees raised the value of land relative to labour, increasing farm sizes and creating both sale and rental markets.

The distinction between geographic and institutional explanations has therefore become blurred. Alsan (2014) shows that ethnic groups located in tsetse-suitable areas were less likely to use domesticated animals and the plough. Consequently their settlement patterns were low density. Nevertheless, the mechanism through which these past effects persist into the present relies on pre-colonial political centralisation, as suggested by others. But in new, unpublished work, Michalopoulos, Papaioannou and Weil (2016) argue that political centralisation may itself be a consequence of geography: they find that the descendants of pre-colonial pastoralists are today more likely to be poorer than the descendants of agriculturalists. The mechanism through which this effect persists is the inferior treatment of women among those of pastoral ancestry.

Isolating the exact mechanism across a range of countries may not be a fruitful exercise: many likely reasons, contingent on the local environmental, political and economic context, explain why geography or institutions persist or not. Comparing distant historical events to present-day outcomes may also suffer from a 'compression of history', as Austin (2008) warns. We therefore investigate one country that has escaped the attention of economic historians, despite exhibiting many of the features described in the literature. And we do so for several points of observation over time. Did wealth in South Africa persist because of locational advantages (as Maloney and Caicedo (2016) found for most Latin American countries), or did fortunes reverse (much like Acemoglu, et al. (2002) argue for the whole of Africa)? Can we empirically disentangle the complex geographic or institutional mechanisms that underpin such persistence or reversal?

\section{The Great Divergence within South Africa}

One advantage we have in investigating South Africa is that the descendants of the European settlers have remained, to a large extent, a separate com- 
munity from the indigenous, Bantu-speaking peoples. Integration between the Bantu-speaking Africans and the descendants of Europeans was minimal during the first two centuries of settlement, and criminalised during the twentieth century. Even after legalisation and democracy, inter-ethnic marriages remain uncommon.

This feature of South African history and society allows us to investigate the persistence or reversal of wealth within the Bantu-speaking population. As far as we can tell, none of the earlier studies could do this: in Latin America, European settlers mixed with indigenous and slave populations. Any measure of welfare today includes the fortunes of the descendants of European immigrants. Similarly, the reversal of fortune-hypothesis that Acemoglu, et al. (2002) advance includes the descendants of European settlers. Most 'neo-Europes' (such as Australia, New Zealand, Canada and the United States) are today populated by descendants of Europeans; where indigenous populations have remained a separate community, they are a poor minority. The decline in relative and absolute numbers of the indigenous populations over several centuries is due to a combination of diseases such as smallpox that decimated vulnerable populations, the seizing of land and resources and, often, violence and warfare perpetrated by European immigrants. We take the view that comparing initial indigenous populations with descendants of European immigrants distorts the mechanisms of a reversal or persistence of fortunes. South Africa, where the descendants of Bantu-speaking people survive and constitute the majority of the population, we believe, provides a relatively uncontaminated case study of how wealth persists or reverses over two centuries of settlement within the indigenous population.

Although European immigrants already settled South Africa in the midseventeenth century, they did not immediately confront Bantu-speaking peoples. They instead settled at the southwestern tip of the continent, in the quasi-Mediterranean, winter-rainfall climate of the Cape. The region was inhabited by the Khoesan, a heterogenous group of nomadic pastoralists and hunter-gatherers. Under Dutch East India Company rule, the settlement expanded to cover most of this winter-rainfall region. Settler farmers moved east until they met, towards the end of the eighteenth century, the agriculturalist, Bantu-speaking isiXhosa at what became the eastern boundary of the Colony (Elphick and Giliomee 2014).

Bantu-speaking peoples had migrated into southern Africa around two millennia ago, reaching the modern-day northern border - the Limpopo river - of South Africa around 300 AD. In a slow and haphazard process of group fragmentation and augmentation (often with indigenous huntergatherer people), Bantu-speakers settled across modern-day South Africa, except in the semi-arid western half and the quasi-Mediterranean southwest. However, these settlement patterns were in continuous flux, especially during the first decades of the nineteenth century. Around 1815, a series of 
conflicts erupted within and between the Bantu-speaking communities of South Africa. The cause(s) of the conflicts, now known as the mfecane in Zulu or difaqane in Sesotho, remain unsolved (Eldredge 1992); historians have variously attributed these events to the leadership of Shaka, conflict with European farmers on the frontier, the slave and gold trades and, in recent contributions, to the eruption of a volcano on an Indonesian island which caused resource constraints across southern Africa (Garstang, Coleman, and Therrell 2014). But the reason why the mfecane happened is less important here; we are more concerned, instead, with its consequences.

Starting in modern-day Kwazulu-Natal, or Zululand, the mfecane led to large-scale resettlements of people across southern Africa. One defecting group of Zulu, the AmaNdebele under Mzilikazi, migrated northwest and west. They finally settled in modern-day Zimbabwe (Matabeleland), causing widespread disruption on their way. Those resisting the Zulu, like the Ndwandwe, were forced to flee east into modern-day Mozambique, displacing the Tsonga (who in turn fled over the Lubombo Mountains into the northernmost region of South Africa). Others, like the Makololo, moved north, displacing several Tswana-speaking groups (in modern-day South Africa and Botswana), and settling for three decades amongst the Luyi in Barotseland, part of modern-day Zambia and Angola. From here they would later move into modern-day Malawi. And others, dislocated from their former places of residence by repeated Zulu warfare, moved west, settling between the amaXhosa and becoming known as the Mfengu.

Some moved pre-emptively. The Ngwane, hoping to escape Zulu attacks, moved to higher elevations and established the Swazi kingdom in what is now Eswatini. Moshoeshoe I also moved to the rugged mountains of the Drakensberg to create an alliance of Sotho groups against the Zulu, which later became known as Basutoland, and still later, the Kingdom of Lesotho.

As a consequence of the need to secure access to food and other resources and to provide protection against the Zulu, several political entities were born throughout southern Africa, most notably the Swazi and Basuto kingdoms. But protection necessitated not just more centralised states; the refugees consolidated their new kingdoms in rugged areas that provided defence against outsiders. This concentration in rugged areas is found elsewhere in Africa too. The Atlantic slave trade pushed Africans into rugged and less accessible regions to reduce the risk of being enslaved (Nunn and Puga 2012).

When the mfecane dissipated by the 1830s, the spatial distribution of Bantu-speakers had been irrevocably changed. Figure 1 (a) shows regions that were not affected by the mfecane or colonial rule by the 1830s. These were the most densely populated regions, concentrated in the high-rainfall, rugged areas of the east coast of South Africa, and inhabited by a collection of amaXhosa clans like the Pondo, the Thembu and the immigrant Mfengu, and further up along the coast, the Zulu of Zululand and the Swazi of Swazi- 
land. The open, flat interior of the country, formerly home to mostly Sotho and Tswana, had been devastated by conflict. Survivors moved either north into modern-day Botswana or found refuge in the Drakensberg mountains (the Basotho).

Recent archaeological evidence supports the contention that indigenous settlement patterns were not static before European arrival. Sadr and Rodier (2012) use Google Earth satellite imagery to identify dispersed precolonial homesteads and nucleated towns in the Suikerbosrand Nature Reserve close to Johannesburg. Inhabited during the fifteenth to the seventeenth century, the settlement disappeared because of 'climate change, conflict and other factors' (Sadr and Rodier 2012, p. 1034). The Suikerbosrand settlement also 'echo[es] similar patterns reported in the neighboring North West Province, where they have been interpreted as a sequence of evolution in social, political and economic complexity' (Sadr and Rodier 2012, p. 1034).

The wars and dispersal at the beginning of the nineteenth century had consequences that were different from earlier periods of turmoil. The mfecane had left much of the South African interior uninhabited by the 1830s. This quasi-desertification allowed bands of European settlers of Dutch descent to move deeper into the interior of the country, at low risk. Figure 1 (a) shows the routes that these settlers followed into the interior. There is still little agreement on the reasons these Voortrekkers left the Cape Colony: the ongoing frontier conflicts with the amaXhosa (Africa's Hundred Years War, from 1789 to 1889), the arrival of large numbers of British settlers (in 1820), a hostile British government (which had taken control of the Cape in 1806 and introduced new policies, in the late 1820s, that affected access to land and labour), and the emancipation of slaves (in 1834) are just several reasons touted for the migration. Beginning in 1836, several thousand frontier farmers moved deeper into the South African interior. Although there is no doubt that these push-factors could have been important, the pull-factor of abundant land obtained at relatively low risk must have been appealing too, especially for highly indebted land speculators in the Colony. The Voortrekkers were not welcomed everywhere they arrived. Several skirmishes ensued, most notably when they arrived in Zululand. As a consequence, the Voortrekkers avoided those areas that were densely populated by Bantuspeaking groups and settled instead in those areas left largely vacant by the mfecane (Etherington 2004b).

These Voortrekkers quickly brought the political and economic institutions they had left behind to the new regions of settlement. The South African Republic (which was formally recognised by Britain under the Sand River Convention treaty in 1852) protected the right of farmers across the Vaal River to govern themselves. A second Boer republic - the Orange Free State - gained independence in 1854. The new states provided full rights to all citizens who had resided in the territory for at least six months. These 
rights included property ownership and the vote for the legislative authority (the Volksraad or People's Council), every five years. Of course, there was one notable exception: only white immigrants and their descendants could be citizens.

These whites would benefit most from the discovery, in 1867, of vast quantities of diamonds on the Orange Free State and Cape Colony border (Cilliers and Fourie 2018). The discovery of diamonds, and of gold twenty years later, reorientated the economic power of the region from the coast to the interior (Feinstein 2005). Thousands of immigrants arrived from Europe and elsewhere, pulled by the promises of quick fortunes; as a result, many profited. Some original inhabitants of the region benefited too; for instance, some Basuto farmers suddenly had a ready market for their produce (Bundy 1979). But the construction of the railways to Kimberley and Johannesburg to supply the mines with equipment, and the surrounding towns with foodstuffs and manufactures, dragged down the Basuto economy (Herranz-Loncan and Fourie 2017). The mines, of course, demanded labour. Although many Bantu-speakers flocked to (or were sent to the mines by their chiefs), their living conditions and bargaining power soon declined, making mining less attractive to them. The colonial governments responded by instituting head and other taxes to forcibly increase the supply of labour. Mines also offered only temporary accommodation for these migrating black mine workers, adopting a system of migrant labour (Wilson 2001).

The political and economic institutions that favoured growth - a la Acemoglu, et al. (2002) - were thus embedded in the new Boer republics to the benefit of the white community. Attempts were made to extend property rights to the Bantu-speaking groups. The Glen Grey Act of 1894, for instance, extended individual land holdings to areas in the Cape Colony that were then under communal ownership. However, these policies were mostly sinister attempts at racial segregation, hoping to increase the supply of labour on the mines or boost fiscal revenue. They seldom had the benefit of boosting Bantu-speaking participation in the market economy. Although 'coloured' (descendants of slave, Khoesan, black and European liaisons) and Bantu-speaking (black) property owners could vote in the Cape Colony, the unification of the two British colonies (Cape and Natal) with the two former Boer republics into the Union of South Africa in 1910 abolished many of these rights. The two British protectorates, Basutoland and Swaziland, remained separate political entities, becoming independent countries in 1966 and 1968 respectively.

Over the course of the twentieth century, coloured and black inhabitants increasingly lost political and economic rights in 'white South Africa'. The Bantu Land Act of 1913 was the first policy of the Union to formally regulate the acquisition of land by blacks. It created black 'reserves' in those areas where black settlement was most dense, an area less than $10 \%$ of the Union, and introduced certain restrictions on blacks owning land outside 
the reserves. The reserve boundaries are shown in figure 1(b). The purpose was ostensibly to reduce the status of black sharecroppers to tenant farmers, increasing black tenant labourers on white farms, and to limit the possibility that blacks could repurchase white-owned land. The law was amended in 1936, increasing the proportion of reserve land to 13\%. Mpeta et al. (2018) use data on individual heights to show that black living standards declined significantly during the first three decades of the twentieth century.

After the National Party victory of 1948, apartheid policies were introduced that not only segregated whites from other races within towns and cities, but, through the Grand Apartheid policies of 'separate development' introduced in the 1950s and 1960s, created homelands - or Bantustans for the different black ethnic groups residing in South Africa. These homelands often matched the borders of the reserves established earlier, but now with the intent of establishing self-governing, semi-independent states. The ultimate aim was to make blacks living within the borders of South Africa nationals of the homelands instead of the newly formed Republic of South Africa, a policy which was eventually made concrete by the Black Homelands Citizenship Act of 1970. Four of the homelands - Transkei (Xhosa), Bophuthatswana (Tswana), Venda, and Ciskei (Xhosa) - were declared independent states, while three others, KwaZulu (Zulu), Lebowa (North Sotho) and Qwaqwa (South Sotho) received partial independence. Independence was never recognized outside South Africa. Separate development also affected the spatial distribution of people: to adhere to the ethnic restrictions placed on settlement, large numbers of blacks were relocated - up to 3.5 million people (Abel 2015). Almost all resettlements were from 'white South Africa' to the homelands.

These homelands often had little economic security to offer. Land was limited and ownership communal; land use rights depended largely on the goodwill of the chief or headman. Moreover, chiefs were often not elected but appointed by the apartheid government. According to Burger (2018, p. 222), '[T]he apartheid government used the tribal system to maintain control over the black population in traditional areas, appointing and dismissing chiefs on the basis of their cooperation with the apartheid government and its various structures. If a chief was not cooperating to the satisfaction of the government he was deposed and replaced'. He explains how councillors in the homelands were appointed by (white) commissioners and black taxpayers, but that commissioner could overrule anyone elected by taxpayers. 'This rigged the system and ensured that resistance from within the governance structures to apartheid rule was minimised' (Burger 2018, p. 222).

The policy of segregation and, later, separate development was an attempt by the apartheid government to push back against the large-scale urbanization of blacks that had followed the high economic growth rates of South Africa from the mid-1930s until the early 1970s. Although apartheid policies prevented blacks from benefiting directly from political and eco- 
nomic institutions, rapid growth in urban areas created economic opportunities on a scale much bigger than those on offer in the homelands. Attempts at industrial policy were largely ineffective at relocating industry to the peripheries of the homeland borders (Lowenberg 1997).

The apartheid government and its skewed institutions of ownership were only replaced by democracy in the early 1990s. Only then did all South Africans enjoy the right to acquire and own property, and move without restrictions. While changes in property rights did occur in former "white South Africa', the economic institutions of the former homelands remained largely the same, with communal ownership dominating. One of the features of post-apartheid South Africa is the large rates of internal migration of both men and women from the former homelands (von Fintel and Moses 2017).

This changing institutional landscape provides one reason for complicating the binary long-run outcomes proposed by Acemoglu, et al. (2002) and Maloney and Caicedo (2016). Whether the transitory institutional arrangements of the nineteenth century would have the same effect on black living standards as the increasingly repressive and discriminatory institutions of twentieth century 'white South Africa' is unclear. Nor is it clear whether the institutions of the native reserves and later Bantustans, or of the independent nations of Lesotho and Swaziland, would result in similar outcomes before and after democracy in South Africa. By considering only the indigenous population and by splitting the period of analysis into three parts, we investigate how settlement and fortune persisted or reversed over nearly two centuries. A less compressed history may offer better insights into how geography and institutions interact to explain contemporary settlement patterns and living standards, and which mechanisms may be responsible for this persistence or reversal.

\section{Data}

To measure the persistence of population density across two centuries, we make use of two new datasets. Firstly, we infer 19th century (post-mfecane) black settlement patterns from digitised historical maps (Walker 1922). Because no figures for population density of Bantu-speaking peoples and their spatial distribution exist in this period, we only infer their approximate locations. Areas that were not devastated by the mfecane and which were located outside British colonial territories are assumed to have been settled by indigenous populations. Critics believe that Walker's maps were more accurate than those previously drawn, but may not have indicated the full extent of black settlement (Etherington 2004a). However, we argue that settler migrant routes partially verify these patterns.

The bands of Voortrekker migrants moved somewhat arbitrarily into the interior, attempting to circumvent densely-populated areas to avoid conflict, with no obvious end destination in mind. They could do this because of the 
devastation caused by the mfecane which had consolidated Bantu-speaking tribes into defensible areas and left large tracts of land in the interior only sporadically inhabited by Bantu-speaking people at the time of their migration. As Etherington (2001, p. 323) remarks: 'Powerful chiefs and kings still held the best well-watered defensible positions where agriculture could be practised alongside pastoralism'. Our evidence below is consistent with this view, as white settlers did not migrate to the best agricultural land, which was also densely populated by Bantu-speaking groups in later years (for which figures are available).

Figure 1 (a) provides (inter alia) a map of the routes that these migrants followed. The routes departed from the British colonial frontier, and mostly traversed areas that were unaffected by the mfecane to reach areas that were indicated as abandoned. In some instances, the settlers circumvented areas of black settlement. In the case of the Zulu Kingdom, the settlers first ventured into the territory, before turning around. All indications suggest that the routes were followed to find land that was not occupied by Bantu speakers after the mfecane. Because these trekker routes started on the eastern border of the then Cape Colony, our analysis excludes most of the western parts of what would become the unified South Africa. Historical sources suggest that almost no Bantu-speaking people inhabited this sparsely-populated and semi-arid region.

Secondly we use the population estimates for the 1911 census districts. This census was the first to cover the full territory that encompasses modernday South Africa. Again we exclude the semi-arid western half of South Africa. Finally, we obtain population estimates for similar regions from the 1996 and the 2011 South African censuses. ${ }^{1}$

We are interested in the correlations between population locations and density at the start of the nineteenth century, at the start of the twentieth century and the start of the twenty-first century. Does the spatial distribution of the black population and its density persist over two centuries of remarkable societal change in South Africa? Further, does early population density also predict better modern-day labour market outcomes and local economic conditions? Our empirical analysis attempts to distinguish between geographic and institutional explanations for the observed patterns. To this end, we collate multiple data sources, matching them with the geographic units of analysis of the 1911 census.

Firstly, we obtain district-level geographic and environmental indicators. We incorporate long-run rainfall data made available by climatologists (Willmott and Matsuura 2012). These data are gridded at $0.5 \times 0.5$ degree points for all terrestrial areas across the globe. Their long-run rainfall estimates provide spatial variation in usual precipitation patterns, indicating

\footnotetext{
${ }^{1}$ Many boundary changes emerge across time, so that we apply areal weighting to match later figures to 1911 boundaries.
} 
the potential of the land to be fruitful. We aggregate these grids onto 1911 census demarcations to incorporate into our empirical models. Similarly, we draw in crop suitability indices to understand whether populations moved to regions that could potentially offer food security in the long run. In particular, we follow Galor and Özak (2016), who develop a 0.5 x 0.5 degree caloric suitability index, which adjusts potential crop yields to reflect the nutritional value that could be produced from land in gridded regions.

Following Nunn and Puga (2012), we study district-level indicators of terrain ruggedness. This particular feature does not measure the benefits of location for food security, but for physical security in the context of early political conflicts. This indicator therefore represents the interaction of geography with institutional upheaval.

More direct institutional shocks are also spatially defined. In particular, we study the legacy of the 1913 Land Act. These areas were designated by the new Union government as reserves for blacks. Within the confines of these areas, blacks could own property subject to the communal law systems of traditional chiefs. More importantly, these regions laid the foundation for the apartheid-era Bantustans. The long-run welfare and social effects of creating separate homelands persist to this day (Pienaar and Von Fintel 2014), and would likely have been areas of agglomeration had these institutions not been implemented (Von Fintel 2018). The homelands or Bantustans, created in 1959, were designed to facilitate the 'separate development' of South Africa's different ethnicities. We trace the borders of these homelands and then consider the proportion of the area of each of the 1911 districts that eventually became an apartheid homeland. This serves as an indicator of 20th century institutional shocks that affected the black population in different locations.

We use two outcomes to represent modern welfare. The first is districtspecific unemployment rates sourced from the 1996 and 2011 censuses. Unemployment is a strong correlate of chronic poverty in democratic South Africa (Aliber 2003) and can be directly measured at the local level in census records. ${ }^{2}$ Secondly, we use night lights luminosity in 1996 and 2011, a commonly used measure to represent local economic development (Henderson, Storeygard, and Weil 2012; Von Fintel and Moses 2017). ${ }^{3}$

This paper uses standard econometric techniques - Ordinary Least Squares regressions - to illustrate three propositions. ${ }^{4}$ Firstly, we show that early

\footnotetext{
${ }^{2}$ On the other hand, the incomes recorded in South African census data are poorly reported; welfare estimates are sensitive to assumptions regarding imputations of brackets and implausible reports of zero incomes (Ardington et al. 2006). We therefore do not rely on incomes in analysing the reversal of fortunes.

${ }^{3}$ While we use the broad unemployment rate of black South Africans, we can, of course, not differentiate night lights luminosity by race.

${ }^{4}$ In the online supplementary materials, we repeat the analysis using spatially clustered standard errors, developed by Conley (1999) and coded by Hsiang (2010). Various distance cut-offs are used, ranging from $50 \mathrm{~km}$ to $1000 \mathrm{~km}$. Except where we explicitly state the
} 
19th century black settlement patterns were driven in part by the nutritional potential of the land and the security of rugged terrain. Even if these patterns were prompted by migrations related to the mfecane, the Great Trek, the frontier wars and the internal conflicts that led to the formation of a Union, settlement was focused in areas with suitable conditions for establishing fortune in future. Secondly, we illustrate that the settlement pattern persists into the 21st century, partially facilitated by geographic fundamentals; however, due to institutional shocks, the persistence in population is not equivalent to persistence in fortunes. Instead, regions that provided high potential for food security in the pre-industrial area became high unemployment regions with relatively low night lights luminosity in modern times. Despite two decades of unrestricted movement in democratic South Africa, the persistence of settlement but reversal of fortune remains a feature of the South African landscape.

\section{Evidence of persistence and reversal}

\subsection{Population persistence}

Figure 1 (a) shows the distribution of the indigenous population in 1830. Shaded districts overlap with the areas which Walker (1922) indicated as being unaffected by the Mfecane. These areas continued to be densely populated in 1911 and 2011. Figures 1 (b) and (c) illustrate the locational persistence of the black population distribution in South Africa between 1911 and 2011, a finding similar to that of Krugell (2014). The Xhosa population remains concentrated between the Fish and the Kei rivers and the Zulu population are located largely around Shaka's early-nineteenth century centroid of power in the east of the country. Figure 1(a) indicates that Voortrekker migration routes tended to avoid or circumvent regions that were unaffected by the Mfecane; these areas would eventually be densely populated by indigenous inhabitants in later years. This indicates that 20th and 21st century settlement patterns were already in place by the beginning of the 19th century. These highly populated regions also correspond to the Land Act and homelands borders that were imposed by the early and middle of the 20th century respectively (see Figure 1 (b) and (c)).

Were these initial settlement patterns chosen based on favourable geographic conditions? Figure 2 (a) shows that the regions which were densely inhabited by black South Africans in 1911 were also highly suitable for ensuring potential food security (as represented by the caloric suitability of the land). Most of the Voortrekker settler routes did not navigate to regions with the same potential, except for the isolated parties that ventured into the Zulu kingdom after concluding a treaty with Dingane in 1838. Indigenous populations therefore claimed the best land with the most suitable

contrary, our results are robust to the mode of inference. 

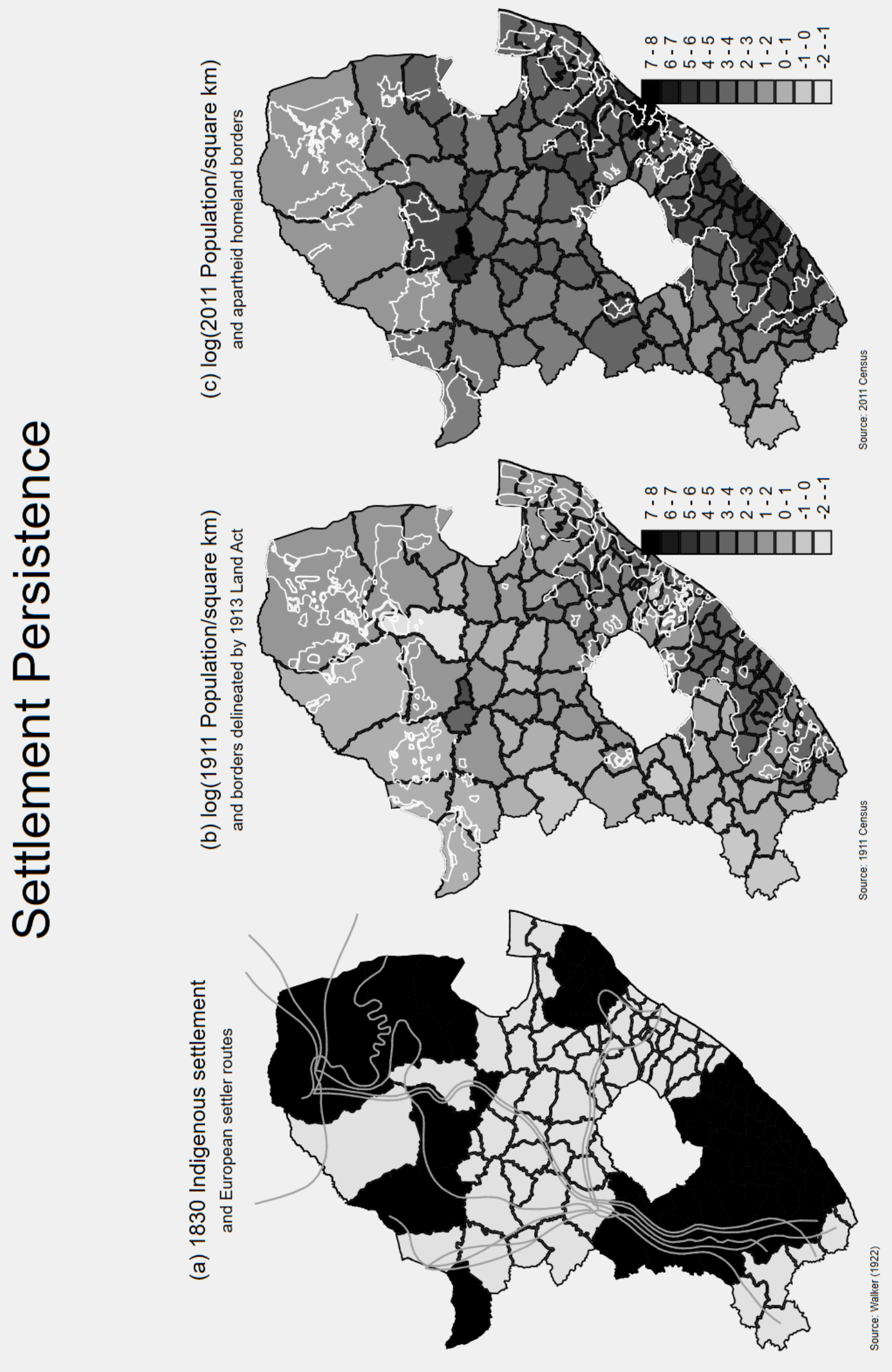

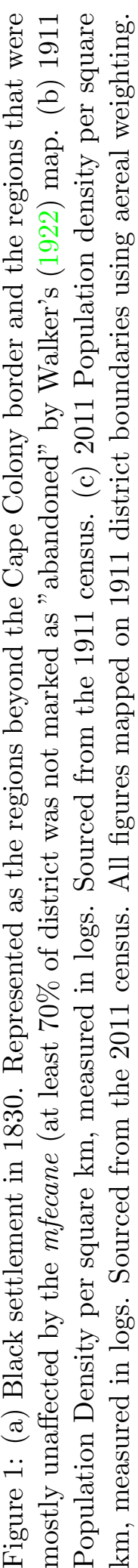




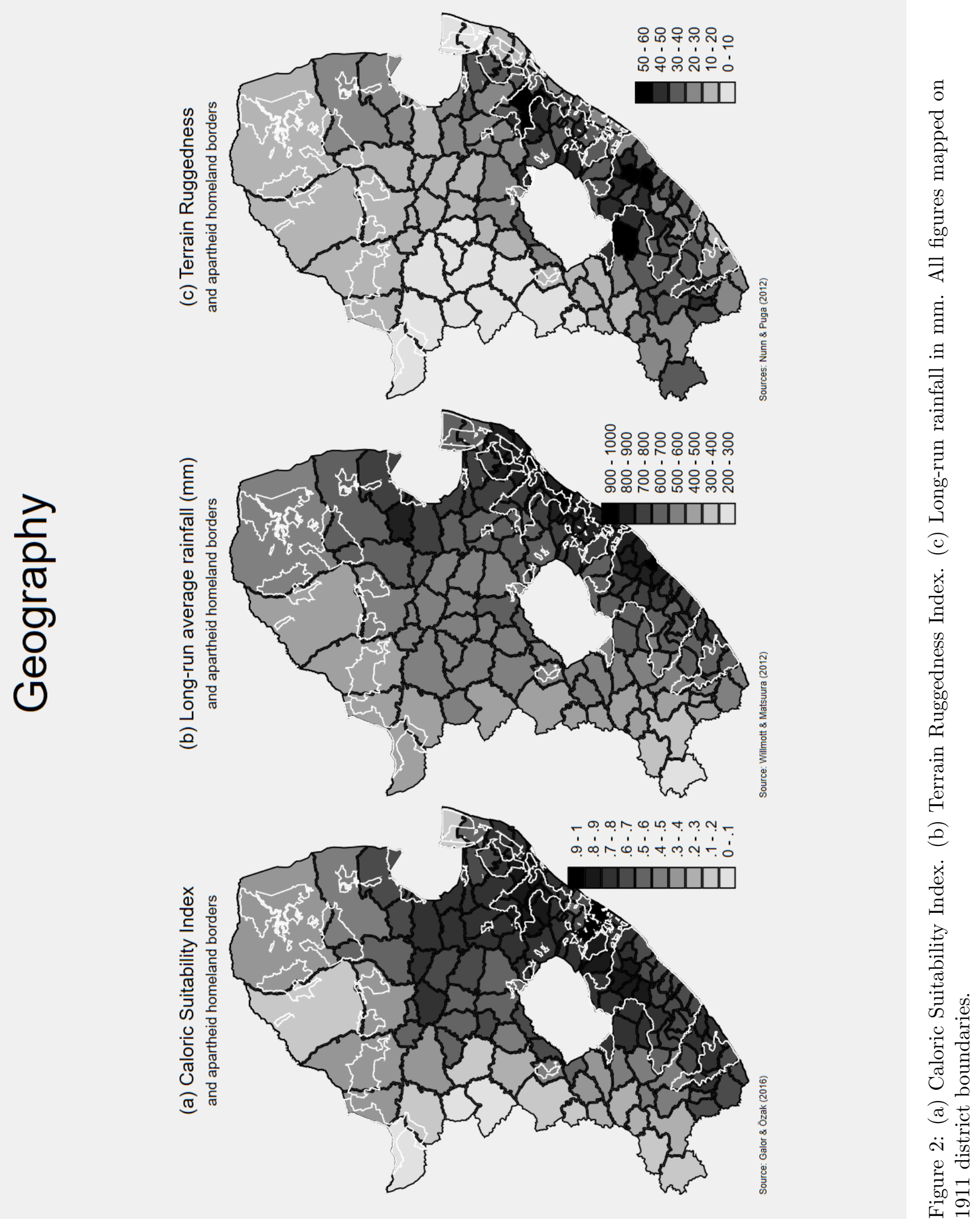


agricultural potential, while settlers followed afterwards and occupied the next best territories, avoiding existing settlements. These patterns are also reflected in long-run rainfall patterns that are depicted in Figure 2(b).

Pre-industrial food security was, however, not the only determinant of black settlement patterns. Conflict did not only motivate the choice of white settler routes, but also the proximate migration patterns of black groups. Figure 2(c) shows that populations settled - partially, at least - in places that were the most rugged in the region. These regions are also known to be adjacent to the locus of the mfecane in the 19th century. They provided security from the ensuing instability in much the same way that Nunn and Puga (2012) attribute the concentration of African populations in rugged terrain to the violence of the slave trade. Putting these factors together, early black settlement patterns were motivated by a combination of the potential for food security and safety from conflict.

Table 1 presents a set of correlation coefficients, and confirms many of the relationships between these factors. While our proxy for early 19th century black population density (Settle1830, or being unaffected by colonial rule or the mfecane) is positively correlated with terain ruggedness (Rugged) and caloric suitability (Soil), a weak negative correlation with rainfall arises. The latter finding is somewhat surprising, but arises due to large settlements in the current-day Free State and North-West provinces, which are typically drier than the eastern part of the country. Zululand and the area that was known as the Transkei during apartheid, both enjoy high rainfall and soil suitability. Black Africans therefore tended to settle in agriculturally suitable regions; the 'bad geography' of these same regions was also favourable at the time that the mfecane was winding down. Settlement in regions with high food potential persisted into later years, except that by 1911 black South Africans were located in more rugged regions, seeking security in the post-mfecane period. On balance, however, population distributions remain strongly correlated over a period of more than 150 years. High density in all historical periods are correlated with high unemployment today.

Table 2 presents Ordinary Least Squares (OLS) regressions to illustrate partial correlations. In the first column, our proxy for early 19th century black settlement patterns is positively correlated with population density in 1911, though its magnitude reduces once we control for rainfall and ruggedness in column two. ${ }^{5}$ The latter are both positively correlated with population density in the early 20th century. This supports our hypothesis that black settlement patterns by 1911 were partially determined by climate and

\footnotetext{
${ }^{5}$ They are only significant at a $10 \%$ level. In the online supplementary material, we show results using Conley (1999) standard errors. Allowing for spatial correlations over short distances reduces the correlations to insignificance at standard levels; once we allow for spatial relationships reaching as far as $1000 \mathrm{~km}$, they become highly significant. We interpret this as evidence for a positive relationship, though measurement error in our proxy variable for 1830 settlement patterns inflates standard errors and reduces significance.
} 


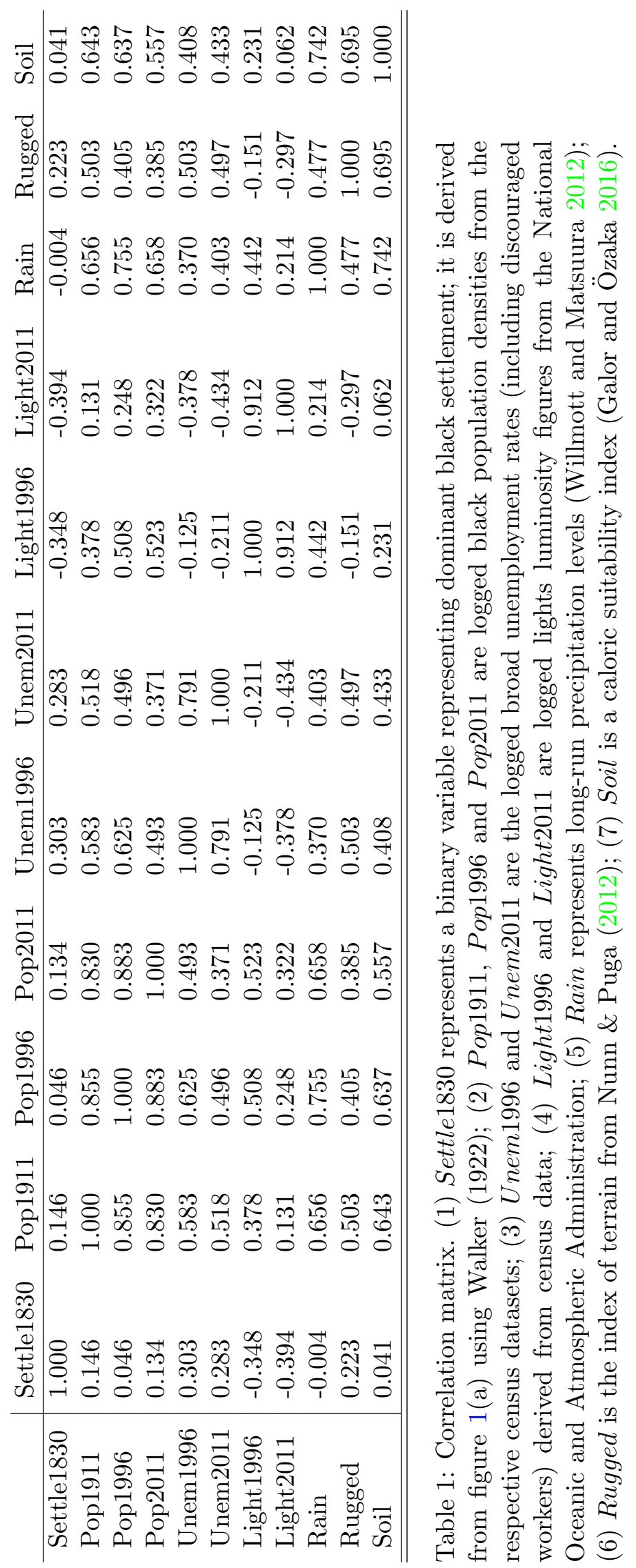




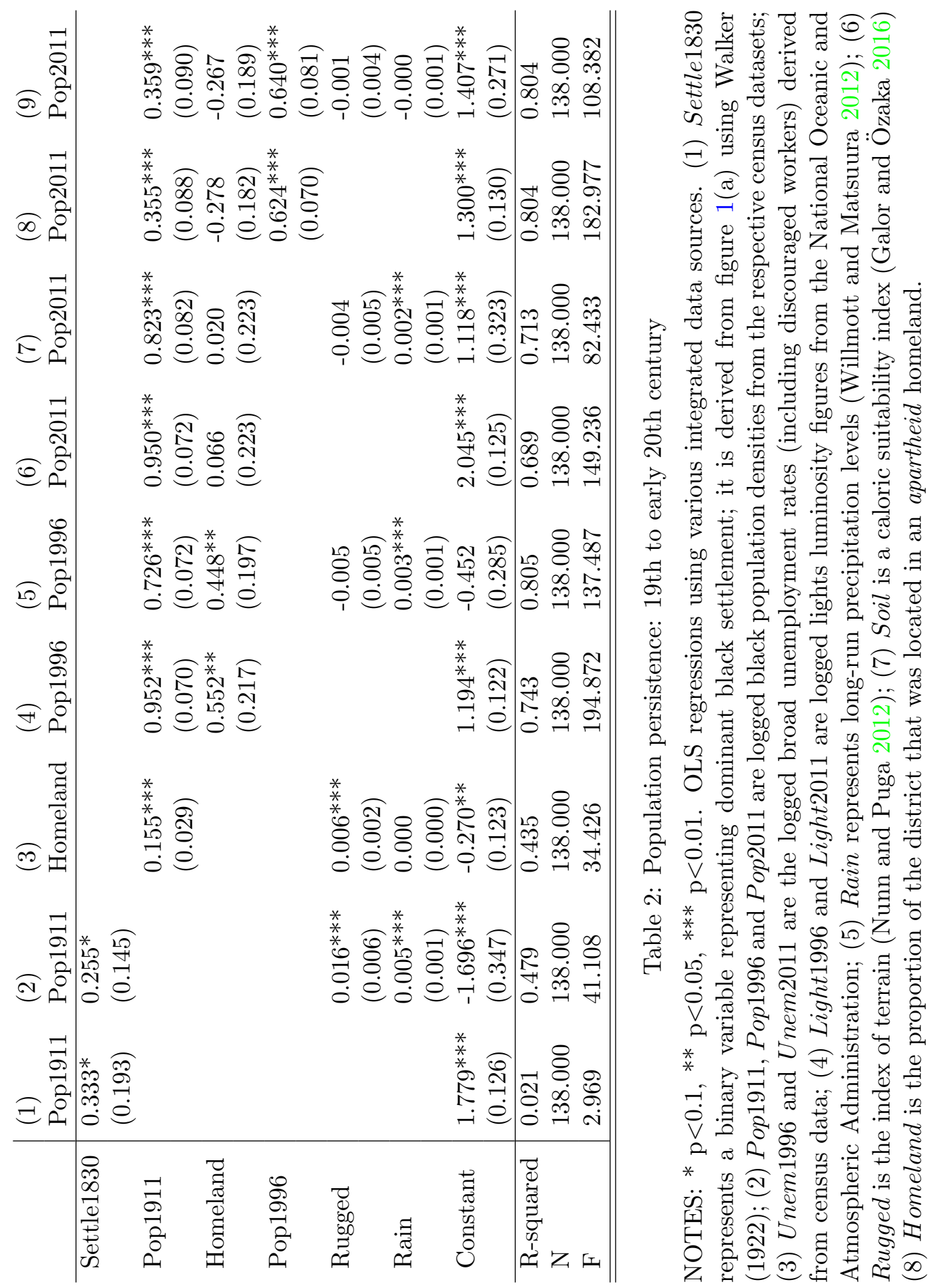


geography of the post-mfecane period, and not only settler movements.

Because our proxy for 1830 black settlement does not measure population density, we continue to use the log of 1911 population density as a predictor for the location of apartheid homelands (column 3), population density in 1996 (columns 4 and 5) and population density in 2011 (columns 6 through 9). In all of these specifications, the population density of 1911 has a positive and statistically significant correlation with later population densities, even when controlling for geographic (ruggedness and rainfall ${ }^{6}$ ) or institutional factors - such as being located in the homelands. And when we regress the 2011 population density on the 1996 population density, while including all controls, 1911 population density still matters independently (albeit with a smaller coefficient). Populations clearly persisted over very long periods.

In 1996, population densities are still strongly determined by whether districts overlapped with the areas that were (at that point) former apartheid homelands (see columns 4 and 5). What is striking, however, is the economic and statistical insignificance of the homeland coefficient by 2011 (columns 6 to 9). While the homeland border still helps to explain settlement in $1996-$ only 10 years after restrictions on movement were lifted in 1986 - the relationship disappears another 15 years later, as migration away from former homelands accelerated. With new institutions and freedom of movement we notice that the relatively recent past - apartheid-era policies - exerts less influence on current settlement decisions than earlier determinants. This suggests one mechanism to mitigate the effects institutional shocks. We will return to a discussion of migration below. By contrast, patterns from the more distant past (1911) still continue to reflect in settlement patterns, so that agglomeration leads to long-run persistence in populations.

\subsection{Reversal of fortunes}

Given the persistence of populations, one might expect a historical persistence of local welfare, in much the same way that Maloney and Caicedo (2016) do for Latin America. Our results complicate this assertion. We assume that densely populated areas before the imposition of the 1913 Land Act were wealthy regions, and show that these are areas of high unemployment today, and - in the case of former homelands - areas where night lights luminosity is lower than the rest of the country. The conflation of historical population densities with initial wealth is an assumption made by both Acemoglu, et al. (2002) and Maloney and Caicedo (2016). Our evidence does support this assumption before white settlement (but after the mfecane): densely populated areas were also regions that were highly suitable to sustain food security and provide physical protection for populations. Some of these early densely-populated regions have been postulated to emerge as

\footnotetext{
${ }^{6}$ We do not control for soil suitability, since the variable is highly correlated with rainfall and terrain ruggedness, and introduces substantial multicollinearity. See table 1
} 
communities with vibrant subsistence agricultural sectors by the end of the nineteenth century (Bundy 1979).

Yet population density may be a poor proxy for wealth in modern economies. Figure 3 (a) shows the spatial distribution of the 2011 broad unemployment rate by 1911 district demarcations. The geographic spread of modern day unemployment corresponds remarkably closely to population density in the early 19th and 20th centuries, indicating that former wealthy regions have become enclaves of poverty. These regions overlap strongly with the former apartheid homelands, so that an institutional explanation may be responsible for this reversal. Furthermore, figure 3 (b) shows that these areas - especially in the south - remain largely under-electrified. Instead, economic well-being, as represented by night lights luminosity, is more pronounced in urban regions that agglomerated around mineral deposits and ports in 'white South Africa'. Night lights are therefore negatively related to early population density in former homelands, and positively in areas beyond that.

Table 3 presents our regression results. While 1911 settlement patterns correlate strongly with 1996 and 2011 unemployment and night lights, fuller specifications (columns 8 and 12) show that more recent changes can account for this persistence. We therefore focus primarily on the role of the homelands in determining modern fortunes. In contrast to the insignificance of the coefficient on homelands when measuring population persistence (in Table 2), it is large and statistically significant in all 10 specifications in table 3. Its sign also follows expectations: unemployment remains higher in the former homelands compared to the rest of the country (columns 1,2 and 6-8), and lights are less bright (columns 3-4 and 9-12). Controlling for geography does not change the core results, so that the fundamentals that were important for welfare in the distant past do not matter for the core argument. Instead, the institutional changes brought about by apartheid have played a defining role in reversing fortunes. Black South Africans living in former homeland areas are poorer today than black South Africans living outside those regions because of an institutional shock.

Twentieth-century institutions, rather than geography, therefore explain most of the reversal of fortune we find, supporting the findings of Acemoglu, et al. (2002). The challenge, of course, is to identify which factors were responsible for this reversal. This is no easy task. Acemoglu, et al. (2002, p. 1262) distinguish between institutions of private property (also called inclusive institutions) and extractive institutions. The former are institutions that 'provide secure property rights, so that those with productive opportunities expect to receive returns from their investments, and are encouraged to undertake such investments'. One condition of such property rights is that they cover a broad cross section of society: 'A society in which a very small fraction of the population, for example, a class of landowners, holds all the wealth and political power may not be the ideal environment for 


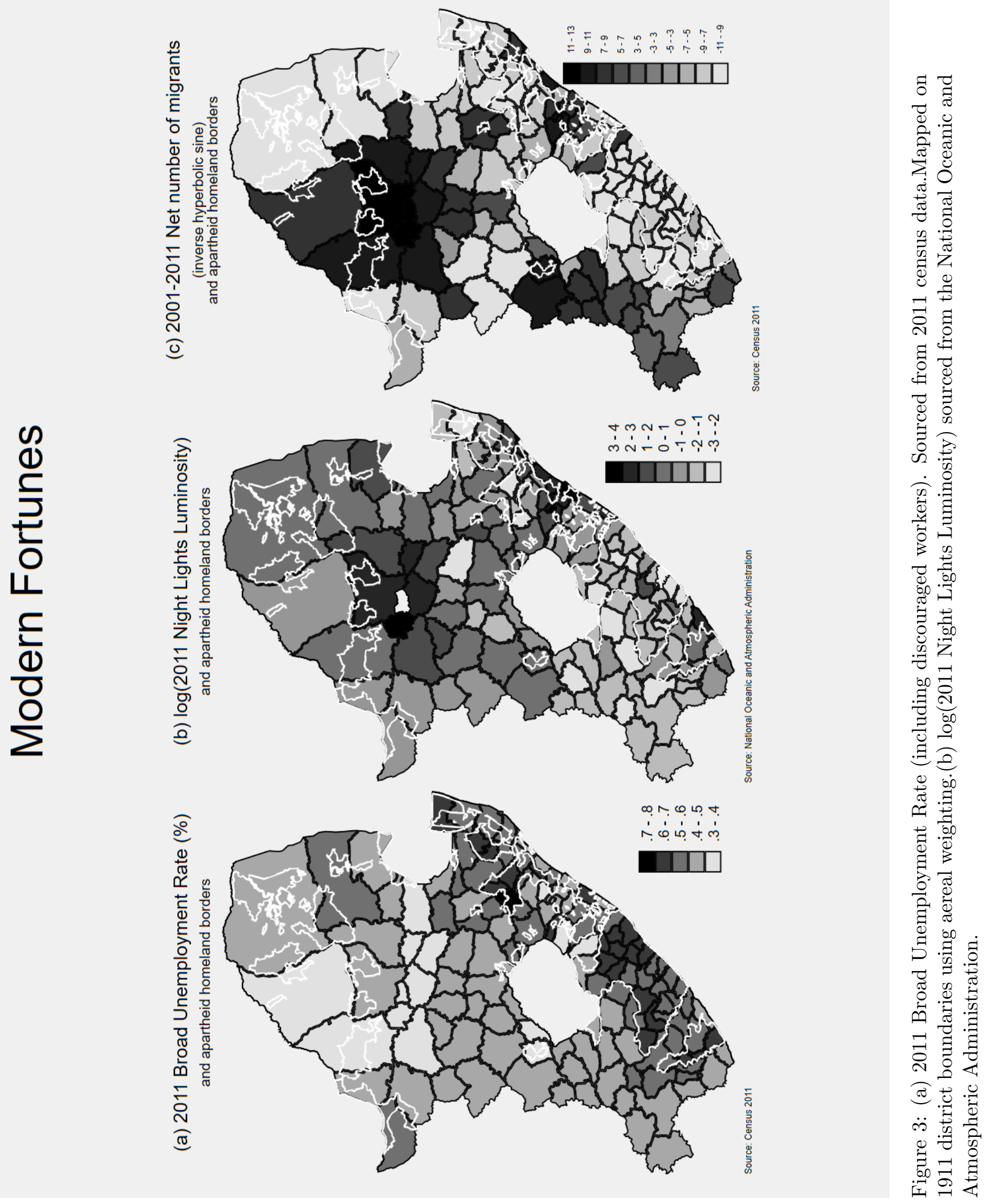




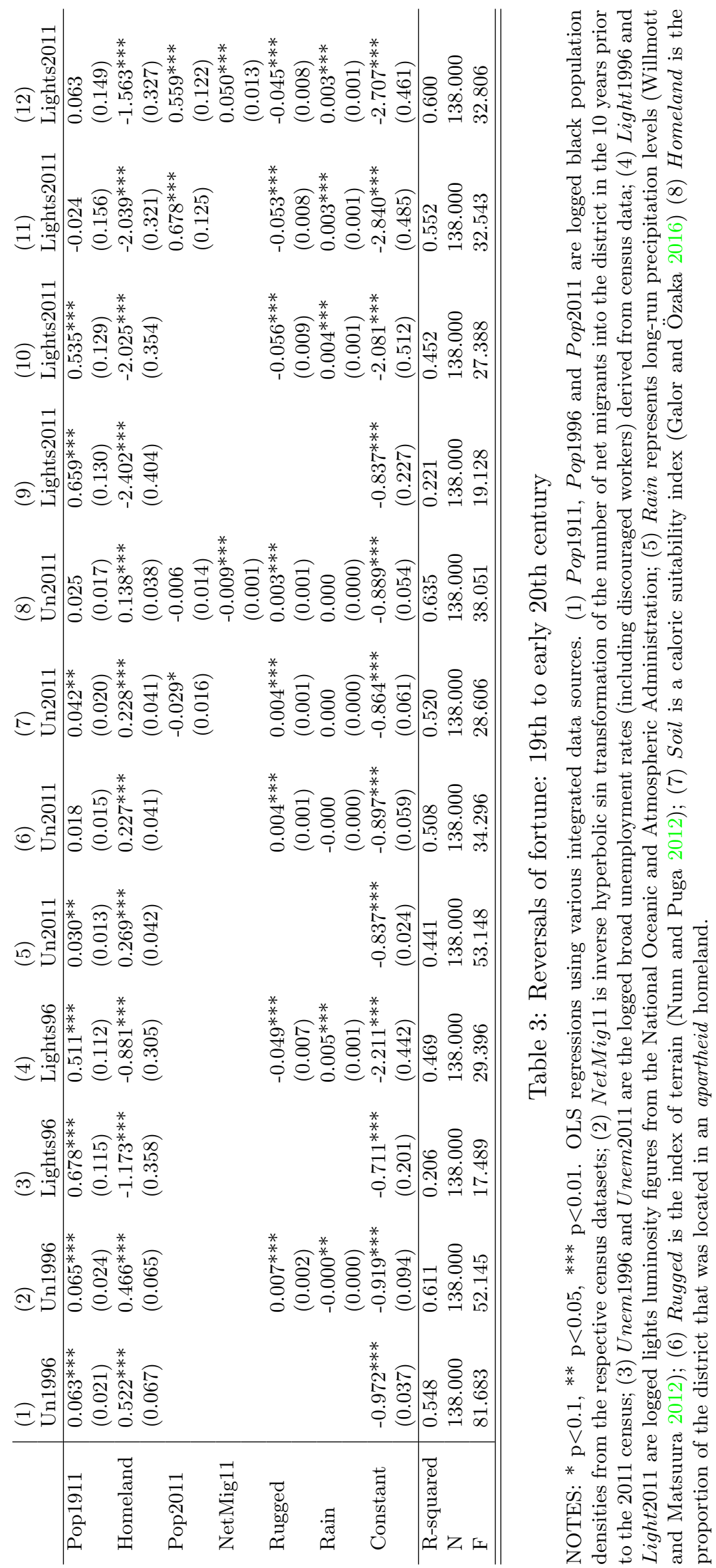


investment, even if the property rights of this elite are secure' (Acemoglu, Johnson, and Robinson 2002, p. 1262). This is an example of extractive institutions.

Such extractive institutions are what black South Africans residing in 'white areas' were subjected to. Several repressive and discriminatory policies against blacks were imposed in 'white South Africa': already by 1911, on the eve of the enactment of the 1913 Land Act, the seeds of racial discrimination had been sown. A battery of legislation was in place to regulate the labour market, with the largest effects targeted at black inhabitants in densely populated regions (including the 1911 Mines and Works Act which enforced the colour bar and job reservation, as well as the 1908 hut taxes that intended to force rural inhabitants into the mainstream labour market).

As the South African economy expanded during the mid-twentieth century, growing at roughly 4\% per year between 1935 and 1970, black wages in 'white South Africa' - despite the many discriminatory apartheid policies began to increase (Mariotti 2012). By the 1970s and 80s, with rising political tension and a domestic and international economic crisis, repressive labour laws were relaxed or abolished. Rapid increases in black wages followed, coupled with rising unemployment. Mechanisation, especially on farms and in manufacturing, set in to contribute to poor labour market conditions. Black migration to the cities increased rapidly, notably after the abolition of influx controls in 1986, forcing the apartheid government to review and ultimately withdraw the system of separate development. When South Africa held its first democratic elections in 1994, black South Africans could live and own property anywhere within the borders of the former 'white South Africa'.

These extractive institutions of twentieth-century 'white South Africa' should, however, be compared to the institutions that evolved in the regions that would become the homelands. The 1913 Land Act, while limiting land ownership to blacks in white areas, also secured the system of traditional rule in what was known as the 'native areas'. The extensions to the Land Act and the more extensive homelands policies established the system of traditional land rights and chiefly power (Delius 2008). Much as they had done before European arrival, chiefs held the prerogative over organising land occupation. There was thus no institutional reversal after European arrival, as Acemoglu, et al. (2002) predicts:

European colonialism led to an institutional reversal, in the sense that regions that were relatively prosperous before the arrival or Europeans were more likely to end up with extractive institutions under European rule than previously poor areas.

No significant institutional reversal - represented by changes in property rights - occurred in South Africa's former homelands after the onset of democracy. Instead, what caused a reversal in fortunes was an institutional 
setting with differential extractive institutions: the large majority of black South Africans were endowed with poor economic and political rights in both 'white South Africa' and the homelands. The Land Acts and homelands policies locked-in the pre-colonial institutions of collective ownership and undemocratic rule, much like the pre-colonial institutions of Basutoland (now Lesotho) and Swaziland (now eSwatini) were locked in at cessation and independence.

These homelands (and Lesotho and eSwatini) were some of the most deprived regions of southern Africa at the coming of democracy. Today, 25 years later, they remain the most poor. ${ }^{7}$ As Noble and Wright (2013, p. 197) show, the 'former homelands experienced high levels of poverty in the immediate post-apartheid era, and ... this continued to be the case at the time of the Census in 2001, and again 6 years later at the time of the 2007 Community Survey'. This is because many of the extractive institutions have remained in one form or another. In fact, Burger (2018, p. 220) argues that in many cases, these institutions have become even more extractive: 'legislation passed by the ANC-government [has] strengthened the powers of traditional chiefs and continue to undermine the tenure rights of the population'. While there are many historical reasons for the low level of development in these regions and countries, including overpopulation, erosion and access to markets, the extractive institutions that persist, an amalgamation of the pre-colonial institutions and apartheid-era interventions, must be an important root cause.

More than a third of black South Africans still live in the former homelands - a remarkable persistence over more than two centuries. These South Africans today, in contrast to their ancestors two centuries ago, are the poorest and most destitute. Geography explains why they inhabited those regions two centuries ago; institutions (and their persistence into the democratic era) why their fortunes have reversed.

\subsection{The mitigating effect of migration}

Because the extractive institutions of insecure private property and undemocratic political processes have remained in the former homelands regions, it is somewhat of a surprise to find that the regional disadvantage declined in the democratic era. As table 3 shows, the institutions of apartheid's homelands exhibit a declining influence on unemployment - the negative coefficients are smaller in 2011 specifications (columns 5 and 6) compared to those in 1996 (columns 1 and 2). Early settlement patterns and institutions created during the 20th century are becoming less important in explaining unemployment.

The reason for this is the abolition of influx controls in 1986 that allowed black South Africans to settle permanently outside the homelands.

\footnotetext{
${ }^{7}$ The 2018 World Development Indicators ranks eSwatini 104th of 178 countries on gross domestic product per capita. Lesotho ranks 149th.
} 
Migration from areas of extractive to inclusive institutions is one way for individuals to escape their historical legacies. In fact, one of the constraints of Acemoglu, et al. (2002) is that it neglects to address the limits to international migration that prevent the inhabitants of those now living in regions with extractive institutions to migrate to regions with inclusive institutions. These limitations indeed held true for South Africa before democracy, when influx control and other restrictions prevented black migrants from settling permanently in 'white South Africa'. When these restrictions were relaxed or abolished, black South Africans, as Tiebout (1956) so eloquently phrased it, 'voted with their feet'.

Figure 3 (c) maps the most recent net migration numbers for the districts under consideration. ${ }^{8}$ Even though significant numbers of South Africans move from urban to other urban areas (von Fintel and Moses 2017), outmigration to other regions is concentrated in the former homelands regions. The exceptions are the homelands located close to urban agglomerations near Gauteng. Regions with relatively low unemployment and high night lights luminosity have positive net migration numbers. These flows reflect the movement from former homelands to areas with more inclusive institutions and better economic opportunities.

Our results confirm that migration mitigates the effect of past institutions. The 'homeland effect' diminishes if we control for net migration (in columns 8 and 12 of table 3 ). Institutional barriers to migration were removed, while institutions of communal land rights remained in place in former homelands. The result has been large rates of urbanisation and migration. Unemployment was partially transferred from sending regions (mainly in the former homelands) to receiving regions (mainly in metropolitan areas), reducing the influence of past institutions on this outcome ${ }^{9}$; the same institutional changes and migration resulted in relative reductions in luminosity in the former compared to the latter areas.

Although migration alleviates some of the unemployment in the former homelands (and, of course, improves the lives of the migrants themselves), it could deepen the disparity between the regions with extractive institutions and those with inclusive institutions, in other words, those within and those outside the former homelands. This is exactly what has happened. Night

\footnotetext{
${ }^{8}$ The number of respondents in the 2011 census who report leaving a particular district for another in the preceding decade, is subtracted from the number of respondents that move into that district from elsewhere. Figures are transformed by the inverse hyperbolic sine function - this approach is similar to a usual log transformation, but accommodates negative net migration values. The variable correlates strongly with reported lifetime movement from respondents' province of birth to another.

${ }^{9}$ The negative sign of the coefficient on net migration in column 8 shows that individuals migrate to areas with low unemployment. The line of causality reflected here is therefore not from migration to unemployment. However, the intention is to factor out the large role of out-migration from the coefficient on homelands. For night lights in column 11 the result is more intuitive - in-migrants may contribute to growing luminosity.
} 
lights in the former homelands areas are becoming dimmer, while remaining bright in other areas that were densely settled in 1911 (compare columns 3-4 and 9-10, showing homelands disadvantages in 1996 and 2011 respectively). This suggests that while individual outcomes - such as unemployment are becoming increasingly de-linked from past geographies and institutions, agglomerations in overall economic activity tend to persist.

\section{Conclusion}

In this paper we empirically investigate this persistence versus reversal debate using the case of South Africa, a country, we argue, that offers an exceptional opportunity to test the role of institutions without the confounding effects of cultural and genetic diversity. Our results allow us to make the following conclusions.

Pre-colonial settlement was not, in the case of South Africa, in a stable Malthusian equilibrium. Disrupted by resource constraints at the beginning of the nineteenth century, perhaps the result of sudden climatic changes, the country entered a period of intense indigenous warfare and migration by European settlers into areas formerly inhabited by indigenous people. Subsequently, Bantu-speaking peoples were locked into the high rainfall, but rugged, inhospitable regions of the country. The newly settled areas, later to be known as 'white areas', developed rapidly as a result of the institutions that were established to benefit whites. Natural resources like diamonds and gold helped, as did access to temporary migrant labour from across southern Africa - the descendants of those affected most by the early nineteenth-century wars. For the few black inhabitants who were allowed to work and reside in 'white South Africa' on a temporary basis under apartheid, the institutions designed for whites would ultimately give them a chance to reverse their fortunes vis-á-vis their black counterparts in the homelands. This divergence in wealth could only happen because limits on the freedom of movement of black inhabitants restricting most of them to the homelands where pre-colonial indigenous land tenure and undemocratic political institutions persisted, often with support of the apartheid-era governments. After the mid-1980s, when the legislative restrictions on black migration were lifted, migration to the urban centres of Gauteng and the Western Cape became the most successful poverty alleviation strategy for residents of the former homelands. Migration has enabled some to cross the divide between the still extractive (and in some cases even more so) institutions of the former homelands and the now inclusive institutions of democratic South Africa, thus to some extent undoing the great divergence that has happened as a consequence.

What do these findings tell us about the debate over the roles of geography and institutions? Geography may indeed be important in determining historical settlement patterns: in agrarian societies, populations tend to set- 
tle in regions with suitable soils, topographical security and high rainfall. But even here one must be cautious in assuming a stable Malthusian equilibrium in pre-colonial times: a sudden climate shock could shift the spatial equilibrium, with long-term consequences. In short: geography is not deterministic. As the history of South Africa demonstrates, settlement was not static in the 1000 years before Europeans arrived in the South African interior; the choice of start-date matters when identifying the degree of persistence of settlement patterns. Neither do institutions inevitably result in a permanent reversal of fortune. The colonial technologies and institutions did indeed help to impoverish black South Africans, but the effects was contingent on the type of institutions in both the 'white areas' and the homelands. Put another way, had institutions been different, the colonisation of the eastern half of South Africa during the nineteenth century might not have resulted in either a persistence of settlement or a reversal of fortune for black South Africans. If the 1910 unification had included provisions that allowed black residents to vote, as was the case in the Cape Colony before, or if it had allowed free movement of all people, South Africa's spatial geography and wealth distribution might be very different today.

The wealth of black South Africans within the borders of the former 'white South Africa' and that of their counterparts in the former homelands have diverged since the start of democracy. Again, there is nothing deterministic about this outcome: had the political processes that created the various acts pertaining to traditional land - notably the Ingonyama Trust Act of 1994 that vested ownership of 2.8 million hectares of KwaZulu-Natal in a sole trustee, the Zulu King Goodwill Zwelethini - been different, it is likely that these regions would have developed much more rapidly. Instead, open borders now allow those who live in regions with extractive institutions to vote with their feet.

Our case study of South Africa made it clear that geography and institutions interact in unpredictable ways. We argue that previous studies have been too inclined to emphasise one of these mechanisms at the expense of the other. Our study showed that historical accidents (like climate shocks or institutional idiosyncrasies) can cause suboptimal equilibria to persist for a long time. The good news of this study is that future South Africa is not necessarily a prisoner to these past equilibria. Addressing the institutional weaknesses of the former homelands is key to alleviating the poverty in those regions where a third of South Africans still reside. 


\section{References}

Abel, Martin (2015). "Long-run effects of forced removal under apartheid on social capital". In: Harvard University Economic History seminar.

Acemoglu, Daron, Simon Johnson, and James Robinson (2005). "The rise of Europe: Atlantic trade, institutional change, and economic growth". In: The American economic review 95.3, pp. 546-579.

Acemoglu, Daron, Simon Johnson, and James A Robinson (2002). "Reversal of fortune: Geography and institutions in the making of the modern world income distribution". In: The Quarterly journal of economics 117.4, pp. 1231-1294.

Acemoglu, Daron and James A Robinson (2010). "Why is Africa poor?" In: Economic history of developing regions 25.1, pp. 21-50.

Aliber, Michael (2003). "Chronic Poverty in South Africa: Incidence, Causes and Policies". In: World Development 31.3, pp. 473 -490. DOI: https: //doi.org/10.1016/S0305-750X(02)00219-X.

Alsan, Marcella (2014). "The effect of the tsetse fly on African development". In: The American Economic Review 105.1, pp. 382-410.

Andersen, Thomas Barnebeck, Carl-Johan Dalgaard, and Pablo Selaya (2016). "Climate and the emergence of global income differences". In: The Review of Economic Studies 83.4, pp. 1334-1363.

Ardington, Cally, David Lam, Murray Leibbrandt, and Matthew Welch (2006). "The sensitivity to key data imputations of recent estimates of income poverty and inequality in South Africa". In: Economic Modelling. Ninth Annual Conference on Econometric Modelling for Africa, School of Economics, University of Cape Town, 2004 23.5, pp. 822-835. DOI: 10.1016/j.econmod.2005.10.009.

Austin, Gareth (2008). "The reversal of fortunethesis and the compression of history: Perspectives from African and comparative economic history". In: Journal of international development 20.8, pp. 996-1027.

Bundy, Colin (1979). The rise and fall of the South African peasantry. Vol. 28. Univ of California Press.

Burger, Philippe (2018). Getting it right: A new economy for South Africa. KMM Review Publishing Company.

Cagé, Julia and Valeria Rueda (2016). "The long-term effects of the printing press in Sub-Saharan Africa". In: American Economic Journal: Applied Economics 8.3, pp. 69-99.

Cilliers, Jeanne and Johan Fourie (2018). "Occupational Mobility during South Africa's Industrial Take-Off". In: South African Journal of Economics 86.1, pp. 3-22.

Collier, Paul and Jan Willem Gunning (1999). "Explaining African economic performance". In: Journal of economic literature 37.1, pp. 64-111. 
Conley, T.G. (1999). "GMM estimation with cross sectional dependence". In: Journal of Econometrics 92.1, pp. 1 -45. DOI: https://doi.org/10. 1016/S0304-4076(98)00084-0.

Delius, Peter (2008). Contested terrain: land rights and chiefly. Juta and Company Ltd, p. 211.

Eldredge, Elizabeth A (1992). "Sources of conflict in southern Africa, c. 1800-30: The Mfecanereconsidered". In: The Journal of African History 33.1, pp. 1-35.

Elphick, Richard and Hermann Giliomee (2014). The Shaping of South African Society, 1652-1840. Wesleyan University Press.

Etherington, Norman (2001). The Great Treks: the transformation of southern Africa, 1815-1854. Longman Pearson.

- (2004a). "A False Emptiness: How Historians May Have Been Misled by Early Nineteenth Century Maps of South-eastern Africa." In: Imago Mundi 56.1, pp. $67-87$.

- (2004b). "A tempest in a teapot? Nineteenth-century contests for land in South Africa's Caledon Valley and the invention of the Mfecane". In: The Journal of African History 45.2, pp. 203-219.

Feinstein, Charles Hilliard (2005). An Economic History of South Africa: conquest, discrimination, and development. Cambridge University Press.

Fenske, James (2014). "Ecology, trade, and states in pre-colonial Africa". In: Journal of the European Economic Association 12.3, pp. 612-640.

Fenske, James and Namrata Kala (2015). "Climate and the slave trade". In: Journal of Development Economics 112, pp. 19-32.

Frankema, Ewout HP (2012). "The origins of formal education in subSaharan Africa: was British rule more benign?" In: European Review of Economic History 16.4, pp. 335-355.

Gallego, Francisco A and Robert Woodberry (2010). "Christian missionaries and education in former African colonies: How competition mattered". In: Journal of African Economies 19.3, pp. 294-329.

Gallup, John Luke and Jeffrey D Sachs (2001). "The economic burden of malaria". In: The American journal of tropical medicine and hygiene 64.1_suppl, pp. 85-96.

Galor, Oded and Ömer Özaka (2016). "The agricultural origins of time preference". In: The American Economic Review 106.10, pp. 3064-3103.

Garstang, Michael, Anthony D Coleman, and Matthew Therrell (2014). "Climate and the mfecane". In: South African Journal of Science 110.5-6, pp. 01-06.

Gennaioli, Nicola and Ilia Rainer (2007). "The modern impact of precolonial centralization in Africa". In: Journal of Economic Growth 12.3, p. 185.

Henderson, J. Vernon, Adam Storeygard, and David N. Weil (2012). "Measuring Economic Growth from Outer Space". en. In: American Economic Review 102.2, pp. 994-1028. DOI: 10.1257/aer.102.2.994. 
Herranz-Loncan, Alfonso and Johan Fourie (2017). "'For the public benefit?' Railways in the British Cape Colony". In: European Review of Economic History In press.

Hsiang, Solomon M. (2010). "Temperatures and cyclones strongly associated with economic production in the Caribbean and Central America". In: Proceedings of the National Academy of Sciences 107.35, pp. 1536715372. DOI: 10.1073/pnas.1009510107. eprint: https://www.pnas.org/ content/107/35/15367.full.pdf.

Kazianga, Harounan, William A Masters, and Margaret S McMillan (2014). "Disease control, demographic change and institutional development in Africa". In: Journal of Development Economics 110, pp. 313-326.

Krugell, Waldo (2014). "The spatial persistence of population and wealth during apartheid: Comparing the 1911 and 2011 censuses". In: Economic History of Developing Regions 29.2, pp. 336-352.

La Porta, Rafael, Florencio Lopez-de Silanes, and Andrei Shleifer (2008). "The economic consequences of legal origins". In: Journal of economic literature 46.2, pp. 285-332.

Lowenberg, Anton D. (1997). "Why South Africa's Apartheid Economy Failed". en. In: Contemporary Economic Policy 15.3, pp. 62-72. DOI: 10.1111/j.1465-7287.1997.tb00478.x.

Maloney, William F and Felipe Valencia Caicedo (2016). "The persistence of (subnational) fortune". In: The Economic Journal 126.598, pp. 23632401.

Mariotti, Martine (2012). "Labour markets during apartheid in South Africa". In: The Economic History Review 65.3, pp. 1100-1122.

Michalopoulos, Stelios and Elias Papaioannou (2013). "Pre-Colonial ethnic institutions and contemporary African development". In: Econometrica 81.1, pp. $113-152$.

Michalopoulos, Stelios, Louis Putterman, and David N Weil (2016). The Influence of Ancestral Lifeways on Individual Economic Outcomes in Sub-Saharan Africa. Tech. rep. National Bureau of Economic Research.

Mpeta, Bokang, Johan Fourie, and Kris Inwood (2018). "Black living standards in South Africa before democracy: New evidence from height". In: South African Journal of Science 114.1-2, pp. 1-8.

Noble, Michael and Gemma Wright (2013). "Using indicators of multiple deprivation to demonstrate the spatial legacy of apartheid in South Africa". In: Social Indicators Research 112.1, pp. 187-201.

Nunn, Nathan and Diego Puga (2012). "Ruggedness: The blessing of bad geography in Africa". In: Review of Economics and Statistics 94.1, pp. 2036.

Osafo-Kwaako, Philip and James A Robinson (2013). "Political centralization in pre-colonial Africa". In: Journal of Comparative Economics 41.1, pp. 6-21. 
Pienaar, P Louw and Dieter P Von Fintel (2014). "Hunger in the former apartheid homelands: determinants of convergence one century after the 1913 Land Act". In: Agrekon 53.4, pp. 38-67.

Sachs, Jeffrey D and Andrew M Warner (1997a). "Fundamental sources of long-run growth". In: The American economic review 87.2, pp. 184-188.

- (1997b). "Sources of slow growth in African economies". In: Journal of African economies 6.3, pp. 335-376.

- (2001). "The curse of natural resources". In: European economic review 45.4 , pp. $827-838$.

Sadr, Karim and Xavier Rodier (2012). "Google Earth, GIS and stone-walled structures in southern Gauteng, South Africa". In: Journal of Archaeological Science 39.4, pp. 1034-1042.

Tiebout, Charles M (1956). "A pure theory of local expenditures". In: Journal of political economy 64.5, pp. 416-424.

Von Fintel, Dieter and Eldridge Moses (2017). "Migration and gender in South Africa: Following bright lights and the fortunes of others?" In: Regional Science Policy \& Practice.

von Fintel, Dieter and Eldridge Moses (2017). "Migration and gender in South Africa: Following bright lights and the fortunes of others?" In: Regional Science Policy 85 Practice 9.4, pp. 251-268.

Von Fintel, Dieter P. (2018). "Long-run spatial inequality in South Africa : early settlement patterns and separate development". English. In: Studies in Economics and Econometrics 42.2, pp. 81-102.

Walker, Eric A. (1922). Historical Atlas of South Africa. Oxford University Press.

Willmott, CJ and K Matsuura (2012). "Terrestrial air temperature: 19002010 gridded monthly time series. Version 3.01". In: Center for Climatic Research, Dep. Of Geography, University of Delaware, Newark. http://climate. geog. udel. edu/ ${ }^{\sim}$ climate.

Wilson, Francis (2001). "Minerals and migrants: how the mining industry has shaped South Africa". In: Daedalus 130.1, pp. 99-121. 